Original research article

\title{
GC-MS Metabolomics profiling and HR-APCI-MS characterization of potential anticancer compounds and antimicrobial activities of extracts from Picrorhiza kurroa roots
}

\author{
Qudsia Tabassam ${ }^{1}$, Tahir Mehmood ${ }^{1,2}{ }^{*}$, Sibtain Ahmed ${ }^{3}$, Shagufta Saeed ${ }^{2}$, Abdul Rauf Raza ${ }^{1}$, \\ Farooq Anwar ${ }^{1}$ \\ ${ }^{1}$ University of Sargodha, Institute of Chemistry, Sargodha-40100, Pakistan \\ ${ }^{2}$ University of Veterinary and Animal Sciences-UVAS, Institute of Biochemistry and Biotechnology, 54000-Lahore, Pakistan \\ ${ }^{3}$ University of California San Diego, 9500 Gilman Drive La Jolla, CA 92093, USA
}

\begin{abstract}
The present study explores pharmacological potential and phytochemicals profiling of Picrorhiza kurroa extracts against mammalian cancer cell lines and pathogenic microbes. Bioactive extracts from roots of Picrorhiza kurroa were recovered in the methanol, $50 \%$ aqueous dichloromethane ( $50: 50 \mathrm{v} / \mathrm{v})$ and $n$-hexane. Antimicrobial activity of the bioactive extracts was assessed against selected strains of bacteria and pathogenic fungi. Aqueous dichloromethane extract showed highest zone of growth inhibition (39.06 $\pm 1.0 \mathrm{~mm})$ towards Staphylococcus aureus bacteria while methanolic extract showed the lowest inhibition $(6.3 \pm 4.1 \mathrm{~mm})$ to Escherichia coli bacteria. The tested extracts such as methanol and aqueous dichloromethane exhibited higher inhibition antifungal activity against Aspergillus flavus compared to Fusarium oxysporum. As far as cytotoxicity (MTT assay) of the tested extracts is concerned, $n$-hexane and aqueous dichloromethane extracts were found to be very active against all cancer cell lines (breast cancer MCF7, MDA-MB-231, SKBR3 and ovarian cancer SKOV3). A preliminary phytochemicals profiling was performed in extracts using GC-MS. Several fractions of active extract were separated with HPLC and analyzed using High Resolution Atmospheric Pressure Chemical Ionization Mass Spectrometry (HR-APCI-MS). Two purified compounds (Dihydromikanolide and 1,3-Dicyclohexyl-4-(cyclohexylimino)-2-(cyclohexylethylamino)-3,4-dihydro-1,3-diazetium) were further evaluated for their anticancer activity against ovarian cancer cell line. Our findings depict that all the tested extracts showed considerable anticancer potential through cell viability assays. The purified compound 1 - Dihydromikanolide from methanolic extract was found to be active against ovarian cancer cells and can be explored as a promising nutra-pharmaceutical candidate against ovarian cancer. However, further studies exploring the molecular pathways and in vivo testing are required.
\end{abstract}

Keywords: Antimicrobial agents; Bioactive extracts; Cell viability assay; Cytotoxicity; GC-MS; HR-APCI-MS; Ovarian cancer; Phytochemicals

Highlights:

- GC-MS phytochemicals profiling in Picrorhiza kurroa root from Pakistani flora.

- Cytotoxic and antimicrobial potential of active extracts is explored.

- Two purified active compounds were characterized by HR-APCI-MS and evaluated for anti-cancer potential.

- Picrorhiza kurroa root extract proved to be a promising therapeutic candidate and its active constituents can be explored for nutrapharmaceutical applications.

\section{Introduction}

Medicinal plants act as a potential key player against various diseases. Modern technology has improved the treatment of a large number of diseases but it is still failing to achieve optimal outcomes according to WHO standard goals: "Health for all" (Calzada et al., 1998; van Herten and van de Water,
1999). Multiple factors are involved behind this; overuse of allopathic medicine, economic factors and side-effects of various drugs. In 2013, WHO developed a plan "which emphasized integration of both complementary and traditional medicine". Scientists are in search of such a physiologically compatible, cost-effective and easily available medicinal system "a system that ensures the achievement of the basic goals of health care" (Sen and Chakraborty, 2016).

\footnotetext{
* Corresponding author: Tahir Mehmood, University of Veterinary and Animal Sciences-UVAS, Institute of Biochemistry and Biotechnology, 54000-Lahore, Pakistan; e-mail: tahir.mehmoodbiochem@uvas.edu.pk http://doi.org/10.32725/jab.2020.017

Submitted: 2020-05-11 • Accepted: 2021-01-18 • Prepublished online: 2021-01-20

J Appl Biomed 19/1: 26-39 • EISSN 1214-0287 • ISSN 1214-021X

(c) 2020 The Authors. Published by University of South Bohemia in České Budějovice, Faculty of Health and Social Sciences.

This is an open access article under the CC BY-NC-ND license.
} 
The plants are composed of secondary metabolites called phytochemicals, such as, flavonoids, alkaloids, phenols, terpenoids and glycosides. These phytochemicals exhibit many pharmacological activities; antioxidant, antimicrobial, cardiovascular, anti-inflammatory and anticancer activities (Hussein and El-Anssary, 2018). Exploring phytochemicals which are being used by traditional healers is a fascinating step to valorize these plants used globally as green technology medicine (Ferrante et al., 2019).

Plants are natural means of strengthening health status approximation. Around 250,000 species of plants are presented worldwide among which $10 \%$ were explored for phytochemical potential (Iqbal et al., 2017). The Picrorhiza kurroa plant belongs to the family Scrophulariaceae and is commonly called Kutki in Nepal, kohr kuti in Pakistan and ktaki in Bhutan (Masood et al., 2015). It can be found in the Himalayan regions of Pakistan, India, Bhutan, China and Nepal at an elevation of 3,000-5,000 m (Kant et al., 2013). It is considered an important perennial herb in Ayurveda traditional medicinal system. It is used to treat multiple infections including asthma, jaundice and diabetes in Pakistan, fever and malaria in China, snake bite and liver disorders in India and cough, cold or diarrhea in Nepal (Narayan and Varshney, 2013).

Among chronic disorders, cancer is the biggest cause of death worldwide after the cardiovascular diseases. Among its all types, ovarian cancer is ranked 5th in the world. Although modern technology has cured many disorders such as Tuberculosis (TB), diarrhea, hepatitis C, polio, typhoid etc. still, in the five-year survival rate of ovarian cancer is less than $47 \%$ (Maru and Hippo, 2019). Ovarian cancer grows and metastasizes inside the ovary or reproductive tract of females. The low survival ratio (47\%) of ovarian cancer is closely linked with its prognosis stage, because the cancer is often diagnosed when its already advanced or metastatic (Mbemi, 2018). In this context, identifying the safe, potent, inexpensive, selective and easily available compounds for clinical therapy of ovarian cancer is required (Soares-Bezerra et al., 2019). Ovarian cancer is a painful emerging issue in the society. There is a need for a system which complies with human needs at all levels. Currently available therapy for ovarian carcinoma is very expensive and it is not easily accessible worldwide, e.g. in rural areas of the subcontinent. Treatment with medicinal plants is as old as mankind itself, roughly around 3.3 billion people in the world used medicinal plants in their everyday life. Almost $60 \%$ of currently available drugs are derived from plants (Kooti et al., 2017).

In this regard, the present study was designed to explore the pharmacological potential including anticancer, antibacterial and antifungal properties of Picrorhiza kurroa extracts and to identify chemical compounds responsible for specific activities. Picrorhiza kurroa extracts were previously tested for nimesulide nephrotoxicity (Siddiqi et al., 2015) and antimalarial activity (Irshad et al., 2011), however there are no studies reporting the anti-cancer activity of Picrorhiza kurroa from Pakistan and its detailed profiling of active constituents/compounds with combinational analytical approach.

\section{Materials and methods}

\section{Reagents and equipment}

All solvents [ $\mathrm{MeOH}, \mathrm{CH}_{2} \mathrm{Cl}_{2} / \mathrm{H}_{2} \mathrm{O}$ (1: 1 ), $n$-hexane] used for extraction were purchased from Sigma-Aldrich (USA) of analytical grade, whereas, the acetonitrile (MeCN) of HPLC grade (Sigma-Aldrich) was used. Freeze drier (Perkin Elmer Cla- rus 680 SQ 8 C) located at School of Pharmacy and GCMS at School of Chemistry, USYD was used. Four different human cancer cell lines (breast cancer MCF7, MDA-MB-231, SKOV-3 and ovarian cancer SKBR-3) were purchased from Life Technologies (UK). Two different types of media (DMEM, RPMI with Fetal bovine serum FBS, glutamine and trypsin-EDTA) and MTT reagent were obtained from Life Technology (UK). The Microplate reader (Perkin Elmer victor X4, USA), Olympus microscope (NAO30, USA), Cell countess (II FL Invitrogen) and Incucyte ${ }^{\circledR}$ (ZOOM Live-cell Analysis System ESSEN $\mathrm{UK}$ ) were used during this work. Milli $\mathrm{Q} \mathrm{H}_{2} \mathrm{O}$ was obtained at School of Pharmacy, University of Sydney (USYD). The HRMS (Bruker amazon SL, ESI, APCI, direct probe) located at School of Chemistry (UNSYD) was used for mass spectral analyses.

\section{Extraction}

Picrorhiza kurroa plant roots were collected from Himalayan regions (Azad Jammu and Kashmir) of Pakistan during winter season of 2018. The identification and authentication of plant was done by Dr. Amin Ullha Shah (a taxonomist at the Department of Botany, University of Sargodha, Sargodha, Pakistan). The sample was washed with $\mathrm{H}_{2} \mathrm{O}$, dried under shed at ambient temperature $\left(10-25{ }^{\circ} \mathrm{C}\right)$ and powder grinded. Extraction was carried out using three different solvents $\left[\mathrm{MeOH}, \mathrm{CH}_{2} \mathrm{Cl}_{2}\right.$ / $\mathrm{H}_{2} \mathrm{O}(1: 1), n$-hexane] to get crude plant extract.

Maceration process with shaking was followed for extraction (Sasidharan and Menon, 2010). The dry sample (10 g) was soaked in solvent $(100 \mathrm{ml})$, stirred for $8 \mathrm{~h}$ on an orbital shaker and filtered over Whatman filter paper. The residue was stirred again $(6 \mathrm{~h})$ in a solvent $(80 \mathrm{ml})$, filtered and the experiment was repeated again with residual mass in a solvent by $60 \mathrm{ml}$ for $4 \mathrm{~h}$ to isolate maximum amount of phytochemicals from the plant (Mahmood et al., 2017). The solvent was evaporated at $40{ }^{\circ} \mathrm{C}$ to get the crude extract. The $\mathrm{H}_{2} \mathrm{O}$ sample could not completely concentrate on rotary evaporator, which was freeze-dried to get a powder form of extracted compound. The extract was transferred in small Eppendorf tubes and stored in a freezer at $-20{ }^{\circ} \mathrm{C}$ prior further experiments.

\section{Antimicrobial activity}

To check the antimicrobial activity, the extracts of Picrorhiza kurroa with varying solvent ratio $\left[\mathrm{MeOH}, \mathrm{CH}_{2} \mathrm{Cl}_{2} / \mathrm{H}_{2} \mathrm{O}(1: 1)\right.$, $n$-hexane] were used at $1 \mathrm{mg} / \mathrm{ml}$ concentration. The susceptibility test was assessed against two Gram-positive (Staphylococcus aureus and Staphylococcus epidermidis) and two Gram-negative Escherichia coli and Klebsiella pneumonia) bacteria. Two fungal strains (Aspergillus flavus and Fusarium oxysporum) were used for evaluating antifungal potential. The fucanazole and streptomycin were used as antifungal and antibacterial drugs as positive control with 150 to $180 \mu \mathrm{g} / \mathrm{ml}$ concentration. All material and media (nutrient broth, nutrient agar) for standard bacterial and fungal cultures was obtained from Institute of Biotechnology and Biochemistry, Arid Agriculture University, Rawalpindi (Pakistan). The growth inhibition was measured through disc diffusion assay by measuring the zone of growth inhibition in $\mathrm{mm}$. The protocol was used according to (Usman et al., 2012).

\section{In vitro cell culture and treatment}

Four human cancer cell lines were used to check the anticancer potential of plant extracts. The MCF7 and MDA-MB-231 breast cancer cell lines were cultured in DMEM (10\% FBS, 1\% streptomycin, penicillin) medium in the incubator preset at $5 \% \mathrm{CO}_{2}, 37^{\circ} \mathrm{C}$. The SKBR3 breast cancer cell line and SKOV3 ovarian cancer cell line were cultured in RPMI (10\% FBS, 5\% 
glutamax, $1 \%$ streptomycin and penicillin) medium in the same incubator. To check the anti-proliferative activity of the plant against the above cell lines, a stock solution of extract was prepared at $500 \mathrm{mg} / \mathrm{ml}$. From the stock solution, $1 \mu \mathrm{l} \mathrm{sam-}$ ple was taken and diluted in $999 \mu \mathrm{l}$ of DMEM and RPMI media to get highest stock concentration $(500 \mu \mathrm{g} / \mathrm{ml})$ and filtered using $0.22 \mu \mathrm{m}$ membrane. Further serial dilution ranging from $500,250,125,62.5$ and $31.25 \mu \mathrm{g} / \mathrm{ml}$ was prepared using the same the media. All samples were prepared in triplicate. The percentage of dimethyl sulphoxide (DMSO) was kept between 0.5-1\%. The two standard drugs Monomethyl auristatin E (MMAE) $1 \mu \mathrm{M}$ and Cisplatin $31.25 \mu \mathrm{g} / \mathrm{ml}$ ) were used as a positive control. The cells were incubated in media at same DMSO concentrations, which were used as a control. The media only was used as a blank for the MTT assay. The cells were counted under Olympus microscope in hemocytometer using Trypan blue dye and also by Countess II FL. The 5000 cells in $100 \mu \mathrm{l}$ media/well were seeded in 96 well Biofil plates. Plate was incubated for $24 \mathrm{~h}$ at $37{ }^{\circ} \mathrm{C}$ under $5 \% \mathrm{CO}_{2}$. After $24 \mathrm{~h}$ the sample, positive control and negative control, were added and plates were incubated for 2 days. The MTT assay was performed to check cell viability.

The cell growth was monitored using incucyte machine for 2 days. The activity was monitored after every two hours and analyzed using the Incucyte ${ }^{\circledR}$ ZOOM integrated analysis software (v2016A) to generate cell growth curves over time (Cruz and Kayser, 2019).

\section{Cytotoxic activity using MTT assay}

After two days of incubation with the samples the media was removed and fresh media with $M T T$ reagent $20 \mu \mathrm{l} / 100 \mathrm{ml}$ media was added in each well. After four-hour incubation, DMSO was added to dissolve the crystals and later a reading was taken at $570 \mathrm{~nm}$ on microplate reader in triplicate for each sample. The cell viability calculation done via the same method as described by Ogbole et al. (2017). The MTT reagent value was subtracted from sample value and control value. Later, each sample value is subtracted from negative control and multiplied by hundred to get cell viability.

\section{Cytotoxic activity based on live-cell analysis}

The extent of cytotoxicity analysis of extracted compounds was monitored through Incucyte ${ }^{\circledR}$ ZOOM Live-cell Analysis System (Essen Bioscience, Ann Arbor, MI, USA). The percentage (\%) confluency relative to time as an indication of cell growth inhibition was monitored after specific interval of time through Incucyte ${ }^{\circledR} \mathrm{ZOOM}$ integrated analysis software (v2016A). The percentage of confluency was measured for control, drug and samples in the starting $2 \mathrm{~h}$ of experiment, during specific intervals and on third day of experiment completion. The graphical form of growth inhibition in term of extent of \% confluency relative to time was plotted using Microsoft excel tool (Cruz and Kayser, 2019).

\section{Separation and fractionation}

Each extract was dissolved in $\mathrm{MeOH}(0.5 \mathrm{~g} / \mathrm{ml})$ and $1 \mathrm{ml}$ of solution was taken and diluted with $9 \mathrm{ml}$ of mobile phase A to make the final concentration of $50 \mathrm{mg} / \mathrm{ml}$. The separation of all three extracts was carried out via Shimadzu Nexra high performance liquid chromatography (HPLC) connected to column (C18, $5 \mu, 250 \mathrm{~mm}$, flow rate $0.5 \mathrm{ml} / \mathrm{min}$ ) through gradient program. Total run time was adjusted to 75 min (Suppl. Table
1). Mobile phase A consisted of MilliQ $\mathrm{H}_{2} \mathrm{O}$ with $1 \% \mathrm{MeCOOH}$, mobile Phase $\mathrm{B}$ was $\mathrm{MeCN}$. The flow rate was maintained at 0.5 $\mathrm{ml} / \mathrm{min}$ and elution monitored at $280 \mathrm{~nm}$ (Seo et al., 2016). All fractions were collected manually and UV active fractions were further analyzed by HR-APCI-MS.

\section{Chemical constituents}

The volatile chemical compounds in $n$-hexane and $\mathrm{MeOH}$ extract were checked by GC-MS Perkin Elmer Clarus 680 SQ $8 C$ system. Total run time was adjusted to $25 \mathrm{~min}$. The He $(99.999 \%)$ gas was used as a carrier gas with flow rate of $1 \mathrm{ml} / \mathrm{min}$ and $2 \mu \mathrm{l}$ injection volume was employed. Results explained with NIST online library (Vijayaram et al., 2016).

\section{Mass spectrometry}

The collected fraction was further analyzed by HR-APCIMS (Bruker Solarix 2xR $7 \mathrm{~T}$ ) with wide $\mathrm{m} / \mathrm{z}$ ratio (400 to 20,000,000) through PDA-detector using direct infusion method. It provides mass value up to 5 decimal places (Milic et al., 2013). To assess the constituents, a $20 \mu \mathrm{l}$ sample was dissolved in $\mathrm{MeOH}$ and applied directly to instrument with $400{ }^{\circ} \mathrm{C}$ vaporization temperature. The results were analyzed via Bruker Solarix2XR software.

\section{Data analysis}

GraphPad Prism and Microsoft Excel were used to assess accuracy of data and for result interpretation. All experimental values was taken as triplicate and standard error was detected for all mean value \pm SD in term of $p$ value through student $T$ test $p<0.05$ (Ikram et al., 2016).

\section{Results and discussion}

\section{Crude extracts}

The maximum yield (54\%) was obtained with aqueous dichloromethane followed by methanol (44\%). On the other side, minimum yield was obtained with $n$-hexane (30\%). Our results are in agreement of Kumar et al. (2010) who reported higher yield with aqueous extract.

\section{Antibacterial activity}

We have investigated three types of Picrorhiza kurroa extract against either Gram-negative or Gram-positive bacterial strains.

Our results showed remarkable growth inhibition effects. The $\mathrm{CH}_{2} \mathrm{Cl}_{2} / \mathrm{H}_{2} \mathrm{O}$ extract reveals higher inhibition effect $(39.5 \pm 1 \mathrm{~mm})$ towards $S$. aureus bacteria and $n$-hexane gives better efficiency $(35.1 \pm 7 \mathrm{~mm})$ against $E$. coli bacteria. Endeavor work presents (Elisha et al., 2017) that plant extracts give higher activity against $E$. coli as we have seen in case of $n$-hexane results. The differences of activities assessed with $\mathrm{MeOH}$ and $\mathrm{CH}_{2} \mathrm{Cl}_{2} / \mathrm{H}_{2} \mathrm{O}$ extracts for Gram-positive bacteria can be linked to variable potency based on their chemical composition and action on peptidoglycan layer of both bacteria types. In the present study, we monitored a significant growth inhibition pattern against $S$. epidermidis for methanolic (27.09 \pm $3 \mathrm{~mm})$ and $\mathrm{CH}_{2} \mathrm{Cl}_{2} / \mathrm{H}_{2} \mathrm{O}(35.1 \pm 3.0 \mathrm{~mm})$ solvent extracts (Table 1). Our results support a previous work in which phenol, flavonoids extracted with polar solvents, such as $\mathrm{MeOH}$ and $\mathrm{H}_{2} \mathrm{O}$, revealed good antimicrobial potential (Truong et al., 2019). 
Table 1. Antibacterial activity of $\mathrm{MeOH}, \mathrm{CH}_{2} \mathrm{Cl}_{2} / \mathrm{H}_{2} \mathrm{O}$ and $n$-hexane extracts from Picrorhiza kurroa roots

\begin{tabular}{|c|c|c|c|c|}
\hline Plant extract $(\mathrm{mg} / \mathrm{ml})$ & $\begin{array}{c}\text { Escherichia coli } \\
\text { (Gram -ve) }\end{array}$ & $\begin{array}{l}\text { Klebsella pneumonia } \\
\text { (Gram -ve) }\end{array}$ & $\begin{array}{c}\text { Staphylococcus epidermidis } \\
\text { (Gram +ve) }\end{array}$ & $\begin{array}{c}\text { Staphylococcus aureus } \\
\text { (Gram +ve) }\end{array}$ \\
\hline $\mathrm{MeOH}$ & $6.3 \pm 4.1^{\mathrm{b}} \mathrm{C}$ & $19.0 \pm 2.0^{c} B$ & $27.1 \pm 3.0^{\mathrm{b}} \mathrm{A}$ & $15.9 \pm 4.3^{c} B$ \\
\hline $\mathrm{CH}_{2} \mathrm{Cl}_{2} / \mathrm{H}_{2} \mathrm{O}$ & $7.3 \pm 6.0^{b} \mathrm{C}$ & $19.6 \pm 5.1^{\mathrm{a}}{ }_{\mathrm{B}}$ & $35.1 \pm 3.0^{\mathrm{a}} \mathrm{A}$ & $39.6 \pm 1.0^{\mathrm{a}} \mathrm{A}$ \\
\hline$n$-hexane & $35.1 \pm 7.0^{\mathrm{a}} \mathrm{A}$ & $30.2 \pm 2.0^{\mathrm{b}} \mathrm{A}$ & $20.4 \pm 8.0^{c}{ }_{B}$ & $29.7 \pm 2.0^{\mathrm{b}} \mathrm{A}$ \\
\hline Streptomycin & $40.5 \pm 4.4^{\mathrm{a}} \mathrm{A}$ & $39.5 \pm 1.0^{\mathrm{a}} \mathrm{A}$ & $38.5 \pm 2.0^{\mathrm{a}} \mathrm{A}$ & $41.1 \pm 7.0^{\mathrm{a}} \mathrm{A}$ \\
\hline
\end{tabular}

Values are means $\pm \mathrm{SD}(n=3)$ of three separate experiments. Different superscript letters within the same column show significant differences of means among extraction solvents. Different capital letter in subscript within the same row show significant differences of means among Picrorhiza kurroa roots. Different subscript letters within the same column indicate significant $(p<0.05)$ differences of means among the extraction medium; Superscript letters within the same row indicate significant $(p<0.05)$ differences of means among different bacterial strains analyses.

\section{Antifungal activity}

Antifungal potential of $\mathrm{MeOH}, \mathrm{CH}_{2} \mathrm{Cl}_{2} / \mathrm{H}_{2} \mathrm{O}$ and $n$-hexane extracts was evaluated based on previous research (Mahlo et al., 2016). All extracts showed growth inhibition activity towards the selected fungal strains (Table 2). The MeOH extract exhibited more efficacy $(20.7 \pm 0.9,28.75 \pm 0.21 \mathrm{~mm})$ as compared to activity $(17.7 \pm 0.9,15.75 \pm 0.32 \mathrm{~mm})$ with $\mathrm{CH}_{2} \mathrm{Cl}_{2} / \mathrm{H}_{2} \mathrm{O}$ extract. Our findings are in line with Suurbaar et al. (2017), who reported the growth inhibition activity of Ricinus commu- nis extracts against fungal strains and observed that methanolic extract was more active than aqueous extract. On the other hand, we found $n$-hexane as a most active extract with $27.2 \pm 0.04 \mathrm{~mm}$ growth inhibition activity against Aspergillus flavus, while minimum $(10.3 \pm 0.2 \mathrm{~mm})$ against Fusarium oxysporum. The potent activity of $n$-hexane extract exhibited in this analysis is in agreement with the investigation of Jameel et al. (2018) who reported antifungal effectiveness of $n$-hexane extract of Capparis decidua.

Table 2. Antifungal activity of polar, partially polar and non-polar extracts from Picrorhiza kurroa roots

\begin{tabular}{lcc}
\hline Plant extract $(\mathrm{mg} / \mathrm{ml})$ & Aspergillus flavus & Fusarium oxysporum \\
\hline $\mathrm{MeOH}$ & $20.7 \pm 0.9^{\mathrm{c}} \mathrm{A}$ & $28.8 \pm 0.2^{\mathrm{b}}{ }_{\mathrm{B}}$ \\
$\mathrm{CH}_{2} \mathrm{Cl}_{2} / \mathrm{H}_{2} \mathrm{O}$ & $17.7 \pm 0.9^{\mathrm{d}} \mathrm{A}$ & $15.8 \pm 0.3^{\mathrm{c}}{ }_{\mathrm{B}}$ \\
$n$-hexane & $27.2 \pm 0.1^{\mathrm{b}} \mathrm{A}$ & $10.3 \pm 0.2^{\mathrm{d}}{ }_{\mathrm{B}}$ \\
Fluconazole drug & $39.0 \pm 0.1^{\mathrm{a}} \mathrm{A}$ & $39.0 \pm 0.5^{\mathrm{a}}{ }_{\mathrm{B}}$ \\
\hline
\end{tabular}

Values are means $\pm \mathrm{SD}(n=3)$ of three separate experiments. Different superscript letters within the same column show significant differences of means among extraction solvents. Different capital letter in subscript within the same row show significant differences of means among Picrorhiza kurroa roots. Different subscript letters within the same column indicate significant $(p<0.05)$ differences of means among the extraction medium; Superscript letters within the same row indicate significant $(p<0.05)$ differences of means among different fungal strains analyses.

\section{Cytotoxic activity using in vitro MTT assay}

$\mathrm{MeOH}, \mathrm{CH}_{2} \mathrm{Cl}_{2} / \mathrm{H}_{2} \mathrm{O}$ and $n$-hexane extracts were screened for their anticancer potential against four mammalian cancer cell lines including three breast cancer (MCF7, SKBR3, MDAMB-231) cell lines and one ovarian cancer (SKOV3) cell line.

All tested extracts exhibited anticancer activity in a dose dependent manner. The samples were analyzed in two-fold serial dilutions having the highest $500 \mu \mathrm{g} / \mathrm{ml}$ and lowest $31.25 \mu \mathrm{g} / \mathrm{ml}$ concentrations. Media with cells only were used as a negative control, while two standard drugs ( $1 \mu \mathrm{M}$ MMAE and $31.25 / \mu \mathrm{g} / \mathrm{ml}$ cisplatin) were used as a positive control. All results were measured in triplicates and are presented in a bar graph in Fig. 1.

All extracts showed cytotoxic behavior against MCF7 cell line Fig.1A. The $500 \mu \mathrm{g} / \mathrm{ml}$ concentration of the $n$-hexane extract was found to be the most cytotoxic agent. The higher activity of $n$-hexane extract may be due to presence of a variety of phenolics or terpenoids (Table 3,4 ) in plant extracts in vivo with significant cytotoxicity value (Abu-Lafi et al., 2019). Our results showed similarity with Roslen et al. (2014) who studied anticancer potential of Melastoma malabathricum extracts against MCF7 cell line and found $n$-hexane fraction to be the most effective as compared to other through cell inhibition assay.

The Fig. $1 \mathrm{~B}$ indicates potential activity of $\mathrm{CH}_{2} \mathrm{Cl}_{2} / \mathrm{H}_{2} \mathrm{O}$ and $n$-hexane extracts against MDA-MB-231, a triple negative breast cancer cell line. There is paucity among modern medicine and theories. Why are few cancers being effective with one medication but not with others? This problem may be solved in future by exploring and modifying purified natural compounds from various sources and testing their activity in vivo to understand the problem, since plant based remedies are natural with low side-effects (Koparde et al., 2019).

Similar dose dependent behavior was observed with SKBR3 in Fig.1C breast cancer cell line (Afshar et al., 2017). The $\mathrm{CH}_{2} \mathrm{Cl}_{2} / \mathrm{H}_{2} \mathrm{O}$ and $n$-hexane extracts showed promising activity as compared to $\mathrm{MeOH}$ fraction, which was no more active against this cell line even at $500 \mu \mathrm{g} / \mathrm{ml}$ concentration.

As can be seen in Fig.1D, all tested extracts showed effective cytotoxic potential against ovarian cancer cell line SKOV3.

The MMAE was found to be a more cytotoxic drug as compared to cisplatin. Our results are in line with those reported in the literature. Plant's crude extracts are usually not effective at their lowest concentration because they contain various compounds that are acting as growth inhibitors while others have antagonist activity. To identify the exact compounds, there is a need to perform phytochemical profiling and then test each compound at different concentration against specific cell lines. This process is still challenging for researchers worldwide due to variation of phyto-constituents composition of various origin and lack of confirmation and purification strategies at all levels (Raks et al., 2018). 


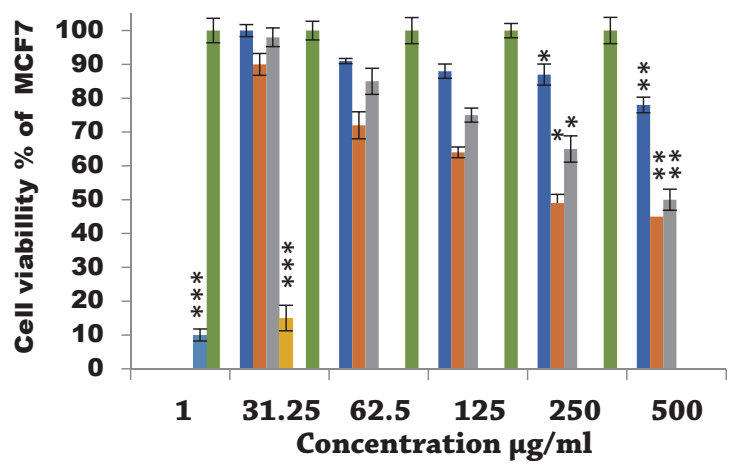

$\mathbf{A}$

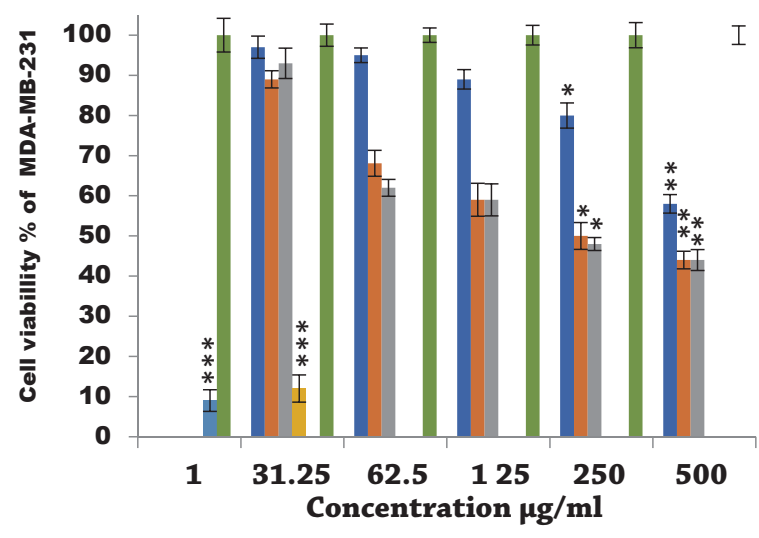

B

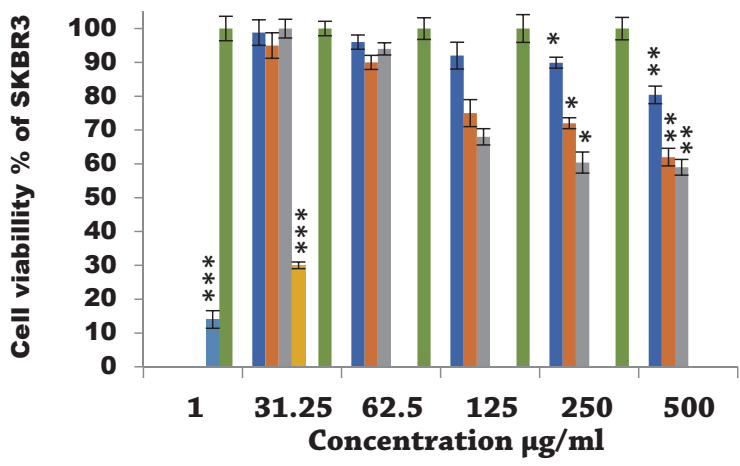

C

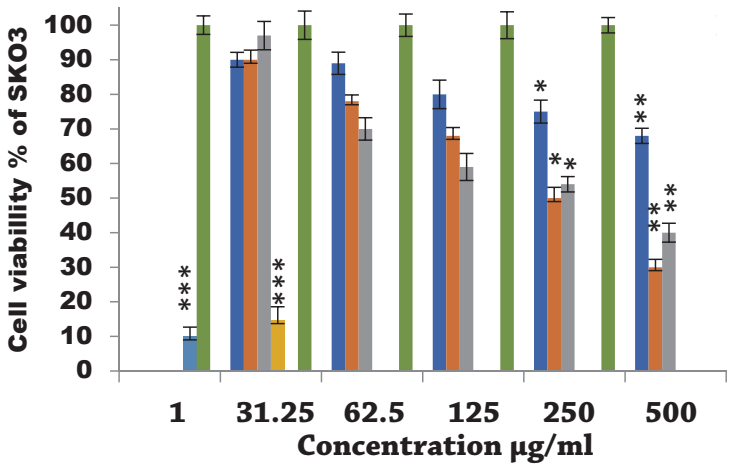

D

Methanol N-hexane Aqueous dichloromethane

Cisplatin

" Monomethyl auristatin E

Control

Fig. 1. Cell viability assay of breast cancer cell lines (A) MCF7, (B) MDAMB-231, (C) SKBR3 and (D) ovarian cancer (SKOV3) cell line. Control is just media with cells showing $100 \%$ cell viability. Two standard drugs used as a positive control are $31.25 \mu \mathrm{g} / \mathrm{ml}$ cisplatin and $1 \mu \mathrm{M}$ monomethyl auristatin E in comparison with activity of plant extracts. All values were taken in triplicate $(n=3)$. There was significant difference observed in all solvent's activity having $p<0.05$. The ${ }^{*}$ indicates the level of significance ${ }^{*}<*<* *$ with standard drug and among extraction solvents.

\section{Bioactive profile}

The GC-MS analysis was performed to make precedent of plant bioactivity. The (Table 3) $n$-hexane and $\mathrm{MeOH}$ (Table 4) extracts were explored for their volatile compounds. The following list summarizes predicted chemicals found in both root extracts of Picrorhiza kurroa plant.

Table 3. GC-MS Metabolomics profile of $n$-hexane extract from Picrorhiza kurroa root (Chromatogram Suppl. Fig. 1)

\begin{tabular}{|c|c|c|c|c|c|c|}
\hline Name of compound & Retention time & Peak area\% & Formula & $\begin{array}{l}\text { Mass } \\
(\mathrm{amu})\end{array}$ & $\begin{array}{l}\text { Class of } \\
\text { compounds }\end{array}$ & $\begin{array}{l}\text { Activities } \\
\text { (reported) }\end{array}$ \\
\hline Heptadecane & 11.34 & 1609 & $\mathrm{C}_{17} \mathrm{H}_{36}$ & 240 & Hydrocarbons & Antidiabetic \\
\hline Palmitic acid & 12.6 & 813 & $\mathrm{C}_{16} \mathrm{H}_{32} \mathrm{O}_{2}$ & 256 & Fatty acid & Antimicrobial \\
\hline Nonadecane & 12.48 & 1773 & $\mathrm{C}_{19} \mathrm{H}_{40}$ & 268 & Hydrocarbons & $\begin{array}{l}\text { Antimicrobial, } \\
\text { cytotoxic }\end{array}$ \\
\hline Octadecenoic acid & 12.89 & 1248 & $\mathrm{C}_{18} \mathrm{H}_{34} \mathrm{O}_{2}$ & 282 & Fatty acid & $\begin{array}{c}\text { Anti-inflammatory, } \\
\text { anticancer }\end{array}$ \\
\hline Methyl stearate & 18.69 & 907 & $\mathrm{C}_{19} \mathrm{H}_{38} \mathrm{O}$ & 298 & Fatty acid & $\begin{array}{c}\text { Antibacterial, } \\
\text { antifungal }\end{array}$ \\
\hline Quercetin & 19.54 & 311 & $\mathrm{C}_{15} \mathrm{H}_{10} \mathrm{O}_{7}$ & 302 & Flavonoid & $\begin{array}{l}\text { Antioxidant, } \\
\text { antimicrobial }\end{array}$ \\
\hline 3-Acetyl- $\beta$-sitosterol & 22.23 & 79 & $\mathrm{C}_{31} \mathrm{H}_{52} \mathrm{O}_{2}$ & 456 & Steroid & Antioxidant \\
\hline
\end{tabular}


Tabassam et al. / J Appl Biomed

Table 4. GC-MS metabolites profile of methanolic extract from Picrorhiza kurroa roots (Chromatogram Suppl. Fig. 2)

\begin{tabular}{|c|c|c|c|c|c|c|}
\hline Name of compound & $\begin{array}{l}\text { Retention } \\
\text { time }\end{array}$ & Peak area\% & Formula & $\begin{array}{l}\text { Mass } \\
(\mathrm{amu})\end{array}$ & $\begin{array}{l}\text { Class of } \\
\text { compounds }\end{array}$ & $\begin{array}{l}\text { Activities } \\
\text { (reported) }\end{array}$ \\
\hline $\begin{array}{l}\text { 8-Methyl-hexahydro-pyrano[3,2-b] pyran- } \\
\text { 2-one }\end{array}$ & 5.63 & 487 & $\mathrm{C}_{9} \mathrm{H}_{14} \mathrm{O}_{3}$ & 170 & Heterocycle & - \\
\hline 1,4-bis(dimethylethyl)- benzene & 5.88 & 160 & $\mathrm{C}_{14} \mathrm{H}_{22}$ & 190 & Hydrocarbon & Antioxidant \\
\hline Heptadecane & 6.35 & 1053 & $\mathrm{C}_{17} \mathrm{H}_{36}$ & 240 & Hydrocarbon & Antidiabetic \\
\hline $\begin{array}{l}\text { (2R,3S)-3-methyl-2-(prop-1'-en-2-yl)-6- } \\
\text { (propan-2'-ylidene)-3-vinylcyclo hexanone }\end{array}$ & 6.48 & 499 & $\mathrm{C}_{15} \mathrm{H}_{22} \mathrm{O}$ & 218 & Sesquiterpenoid & - \\
\hline Methyl cinnamate & 7.26 & 567 & $\mathrm{C}_{10} \mathrm{H}_{10} \mathrm{O}_{2}$ & 162 & Ester & Anticancer \\
\hline $\begin{array}{l}\text { Hexahydro-2H-pyrano[3,2-b] azin-6-(7H)- } \\
\text { one }\end{array}$ & 7.92 & 837 & $\mathrm{C}_{8} \mathrm{H}_{13} \mathrm{NO}_{2}$ & 155 & Alkaloid & - \\
\hline Palmitic acid & 10.33 & 687 & $\mathrm{C}_{17} \mathrm{H}_{34} \mathrm{O}_{2}$ & 270 & Fatty ester & Antidiabetic \\
\hline
\end{tabular}

The broad stream documented history on natural resources indicates that these are composed of potential phytochemicals. As expected, this study highlights the list of phyto-constituents and justifies the quote "plant activity narrates with its bioactive presence" (Krishnamoorthy and Subramaniam, 2014). The explored $\mathrm{MeOH}$ and $n$-hexane extracts enlist phytochemicals, a few of which were explored by initial screen for their antioxidant and antimicrobial activities in a number of other plants, while a few other compounds are still under investigations (Godara et al., 2019; Singh and Chaturvedi, 2019). A compound, namely $\beta$-sitosterol, is studied as a tumor inhibitor anticancer agent in vivo (Abu-Lafi et al., 2019). Palmitic acid and most of the fatty acids are known to show cytotoxic effect against colon cancer (Mericli et al., 2017). Various terpenoids are reported with significant effect on liver cancer cell lines (Thoppil and Bishayee, 2011). The initial screening (presence of bioactives) and literature search of compounds potential helps to make connotation to test these extracts further by highlighting their working activity range, potential mechanism, or search of novel and versatile remedies for chronic diseases.

To overcome the global disease burden in 21st century for the achievement of basic health goals there is an urgency to find out novel bioactive, or modification of existing strategies with different sources in various regions. Nonetheless a single technique is not supposed to be enough for investigation of all the chemical constitutes since extraction with solvent mixtures, techniques and regions have strong effects on bioactivity and novelty of compounds (Qadir et al., 2018). After indications of credible classes of compounds, listed through GC-MS analysis (Table 3 and Table 4), the work was planned to explore individual pharmacological activities.

\section{Mass spectrometry}

The extracts were subjected to HPLC purification. Fractions were collected manually and checked with UV-Vis Spectrophotometer at $280 \mathrm{~nm}$ wavelength (Seo et al., 2016). The active fractions were explored with HR-APCI-MS. The results were processed with Bruker Solarix 2XR software. With the help of molecular mass ( $\mathrm{m} / \mathrm{z}$ to four decimal places in amu units) of molecular ions the molecular formula was worked out using Sci-Finder and METLIN search. This method, for quick compound detection with maximum accuracy, was used as a latest technique to explore phytochemicals as presented in Table 5 (on page 33-34).

\section{Compound's antiproliferative effect}

The following two compounds 1 and 2 shown in (Fig. 2) (HPLCMS Spectrum Suppl. Fig. 3, 4) were semi purified from methanolic and aqueous dichloromethane extracts, which were explored for cytotoxic potential against ovarian cancer.

\section{Live cell count assay and morphological study of cells}

Five thousand cells were seeded in 96 well-plate and after $24 \mathrm{~h}$ cells were treated with different concentrations of sample extract and standard drug. Cell morphology was observed under a microscope. The cells were monitored at zero-time - see Fig. 3A, which shows their confluency. The effect of test compounds 1 and 2 on cells was monitored after 3 days in terms of $\%$ confluency of live cells.

In Fig. 3B, the cells growth represent negative control. As we can see in Fig. 3C, drug (cisplatin $31.25 \mu \mathrm{g} / \mathrm{ml}$ ) cleared zones of cells growth and decreased number of live cells. Fig. 3D shows activity of compound 1 - inhibition of cell growth, which was lower then that casused by the drug.

The live cell count assay was performed with an Incucyte Zoom. The cells were monitored every $2 \mathrm{~h}$ according to the percentage of cells and data curve was generated at the end. The compounds ( 1 and 2 ) of various concentrations were prepared with media and applied in comparison to drug (cisplatin) against ovarian cancer cell line. Cisplatin is one of the active platinum drugs against ovarian cancer. The compound 1 showed potency of cancer cell growth inhibition at $25 \mu \mathrm{g} / \mathrm{ml}$ concentration, while the activity was hindered when lower concentration ranges $12.5-6.5 \mu \mathrm{g} / \mathrm{ml}$ were tested. As an early endeavor our research highlights the cytotoxic potential of these compounds against ovarian cancer cell lines SKOV3 and provides the extent of working range of these chemicals, without wastage of money and time-based outlook for future researchers.

Uncertainty was observed while dealing concerned with compound 2 (1,3-dicyclohexyl-4-(cyclohexylimino)-2-(cyclohexylmethylamino)-3,4-dihydro-1,3-diazetium). Initially the compounds reduced the confluency of cells but on the second day the effect of cell inhibition seemed to be negligible and the cells started to grow and multiply in the same way as in negative control. 
<smiles></smiles>

1 (Dihydomikanolide)

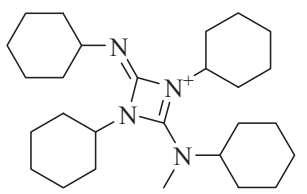

2 (1,3-Dicyclohexyl-4-(cyclohexylimino)-2-(cyclohexyl ethylamino)-3,4-dihydro-1,3-diazetium)

Fig. 2. Structure of compounds 1 and 2 semi purified from $P$. kurroa extracts
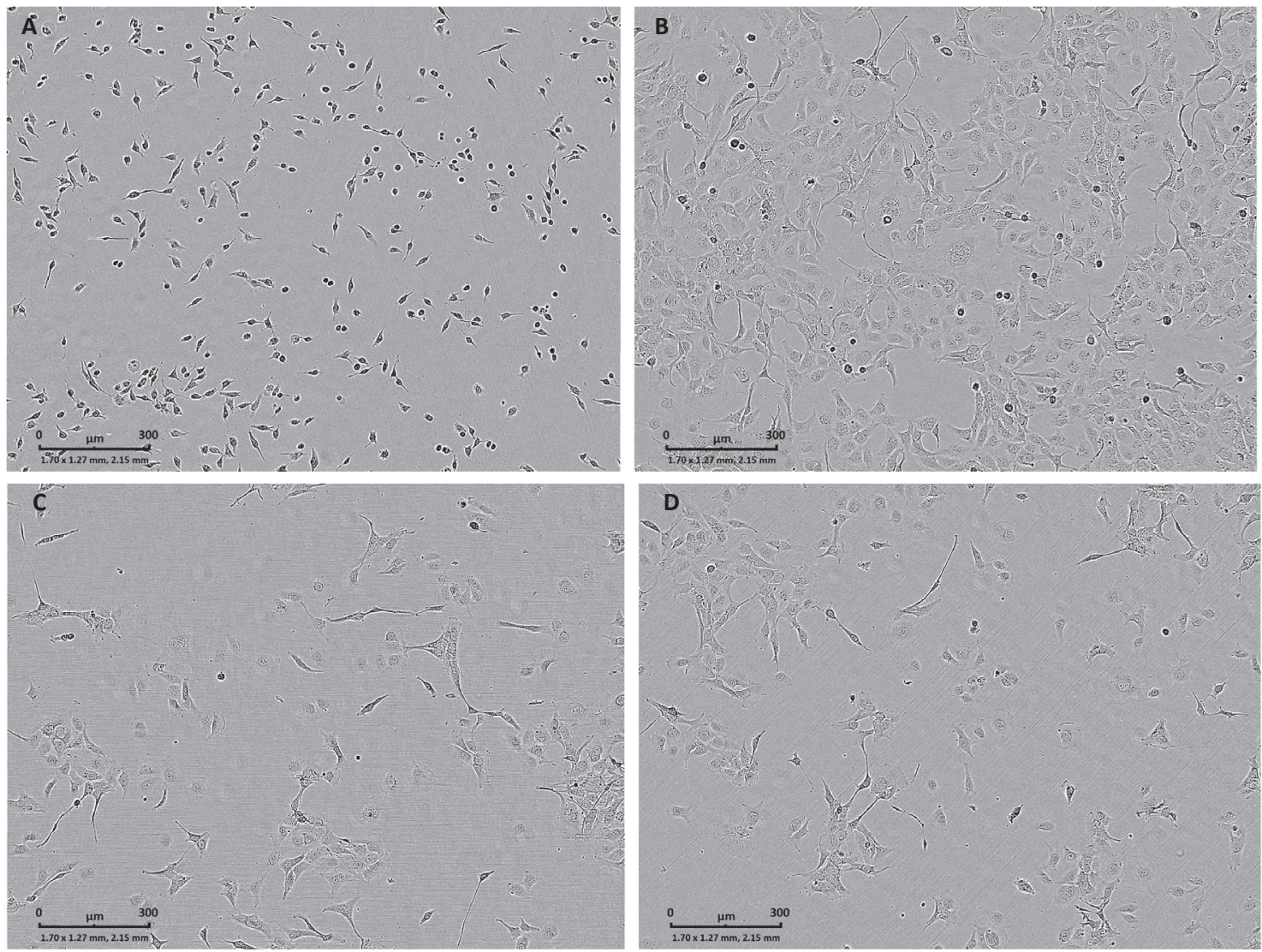

$\mathbf{E}$

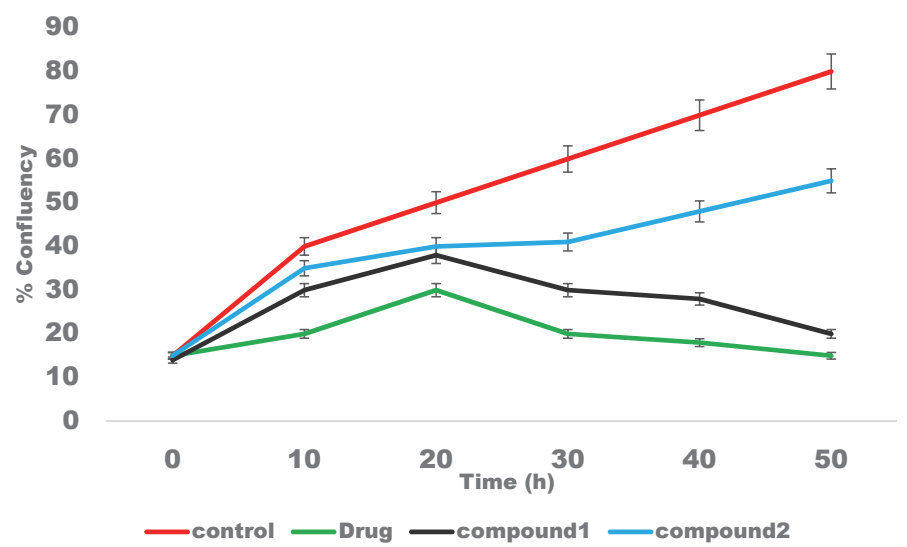

Fig. 3. Inhibition count effects of cells, in term of reduction in \% confluency. (A) time 0 image cells before treatment with drug and compounds (B) negative control, (C) drug (cisplatin) $31.25 \mu \mathrm{g} / \mathrm{ml}$ (D) compound $125 \mu \mathrm{g} / \mathrm{ml}$, (E) growth inhibition curve. After $30 \mathrm{~h}$, the live cells percentage was found to be lower using drug as it is indicated in Fig. 3E. The uniform behavior (just like drug) was observed with compound 1. After 30 hours, reduction in cell growth was observed. 


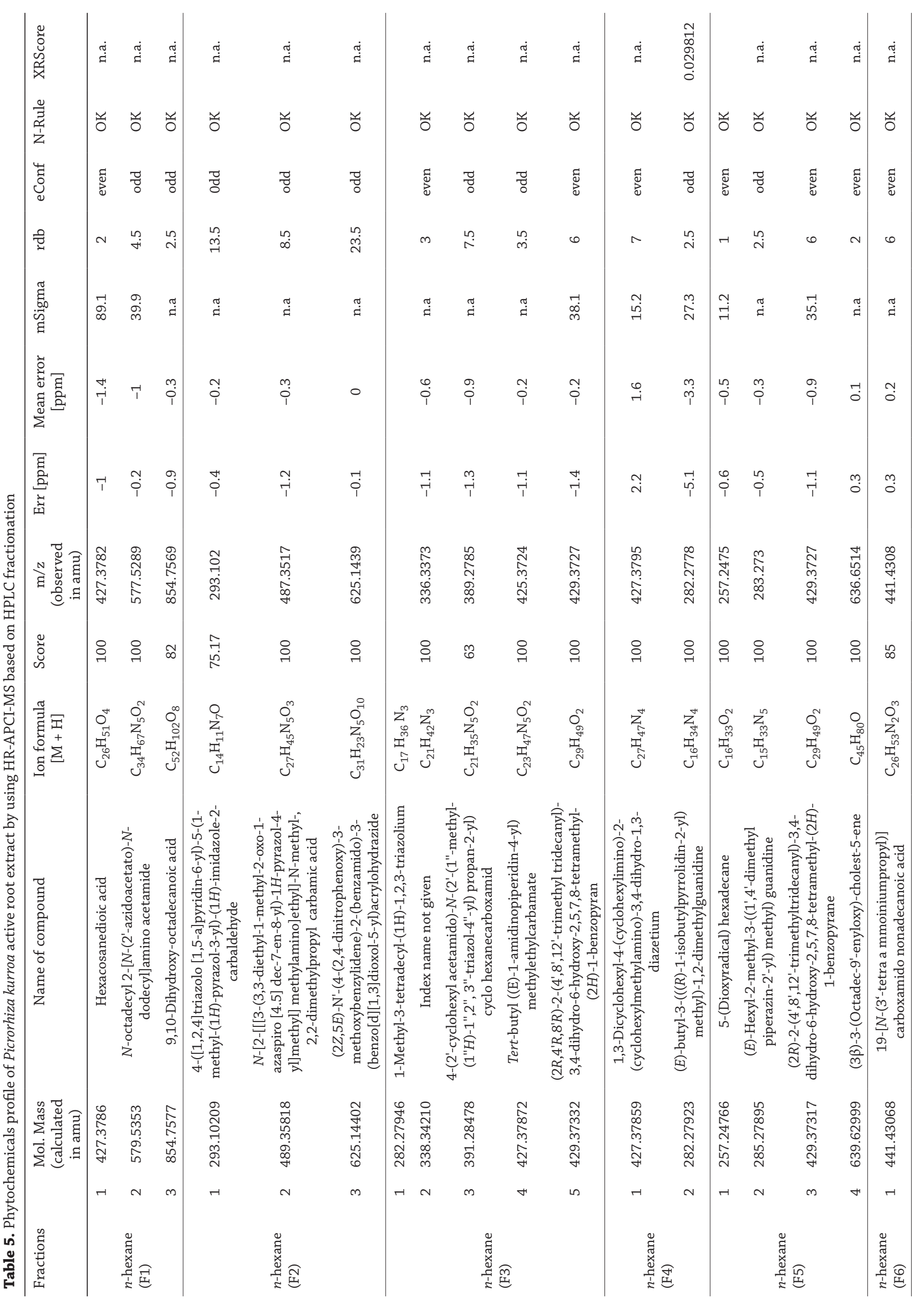




\section{Conclusions}

To the best of our knowledge, the conducted study is the first comprehensive study on P. kurroa medicinal plant from Pakistan. The plant is exploited at various global ethnic regions for its pharmacological activities. We highlighted the list of phytoconstituents, antimicrobial, antifungal and cytotoxic potential of its partially polar $\mathrm{CH}_{2} \mathrm{Cl}_{2} / \mathrm{H}_{2} \mathrm{O}$ fraction followed by other polar $\mathrm{MeOH}$ and non-polar $n$-hexane extracts. We explored its phytochemicals through HR-APCI-MS, which produces almost no/rare fragments and gives compound identification with maximum accuracy. Our results are consistent with traditional healer point of view, who reported previously antimicrobial and cytotoxic potential of the plant. To the best of our knowledge, extracted (partially purified) compounds 1 and 2 are first time explained for its pharmacological potential against ovarian cancer cell lines. Further studies should be conducted to confirm cytotoxic behavior toward normal cells as well as to elaborate their activity against another type of cancer cell lines and in vivo further studies are needed to explore the mechanism of activity.

\section{Conflict of interests}

The authors report no conflict of interests.

\section{Role of the funding source}

The project is funded by University of Sargodha and partially funded by higher education commission (HEC) of Pakistan.

\section{Acknowledgements}

Special thanks to the School of Pharmacy, University of Sydney, Australia for their support for extracts preparation and all cell line work and access to internet software libraries. The IRSIP Scholarship Program of the Higher Education Commission (HEC) of Pakistan, which financially supported us to perform experiments. We are thankful to School of Chemistry, University of Sydney for mass spectral analyses. Thanks to Department of Chemistry, University of Sargodha for all moral, documented and research method designing support.

\section{References}

Abu-Lafi S, Rayan B, Kadan S, Abu-Lafi M, Rayan A (2019). Anticancer activity and phytochemical composition of wild Gundelia tournefortii. Oncol Lett 17: 713-717. DOI: 10.3892/ ol.2018.9602.

Afshar AS, Nematpour FS, Meshkani M, Khafi A (2017). Growth inhibition of human breast cancer cells and down-regulation of ODC1 and ADA genes by Nepeta binaloudensis. Rev Bras Farmacogn 27: 84-90. DOI: 10.1016/j.bjp.2016.07.005.

Calzada F, Alanis AD, Meckes M, Tapia-Contreras A, Cedillo-Rivera R (1998). In vitro susceptibility of Entamoeba histolytica and Giardia lamblia to some medicinal plants used by the people of Southern Mexico. Phyto Res 12(1): 70-72. DOI: 10.1002/(SICI)10991573(19980201)12:1<70::AID-PTR189>3.0.CO;2-V.

Cruz E, Kayser V (2019). Synthesis and enhanced cellular uptake in vitro of anti-HER2 multifunctional gold nanoparticles. Cancers (Basel) 11: 870. DOI: 10.3390/cancers11060870.

Elisha IL, Botha FS, McGaw LJ, Eloff JN (2017). The antibacterial activity of extracts of nine plant species with good activity against Escherichia coli against five other bacteria and cytotoxicity of extracts. BMC Complement Altern Med 17: 133. DOI: 10.1186/ s12906-017-1645-z. 
Ferrante C, Recinella L, Ronci M, Orlando G, Di Simone S, Brunetti L, et al. (2019). Protective effects induced by alcoholic Phlomis fruticosa and Phlomis herba-venti extracts in isolated rat colon: Focus on antioxidant, anti-inflammatory, and antimicrobial activities in vitro. Phytother Res 33: 2387-2400. DOI: 10.1002/ ptr.6429.

Godara P, Dulara BK, Barwer N, Chaudhary NS (2019). Comparative GC-MS analysis of bioactive phytochemicals from different plant parts and callus of Leptadenia reticulata Wight and Arn. Pharmacogn J 11: 129-140. DOI: 10.5530/pj.2019.1.22.

Hussein RA, El-Anssary AA (2018). Plants secondary metabolites: the key drivers of the pharmacological actions of medicinal plants. Herb Med DOI: 10.5772/intechopen.76139.

Ikram MS, Mehmood T, Siddique F, Sattar IA, Tamassam Q, Jabeen Z (2016). Alteration in the blood biochemical parameters and degenerative lesions in Rat liver by a common pyrethroid insecticide (bifenthrin). Pure Appl Biol 5: 1051-1063. DOI: 10.19045/bspab.2016.50130.

Iqbal J, Abbasi BA, Mahmood T, Kanwal S, Ali B, Shah SA, Khalil AT (2017). Plant-derived anticancer agents: A green anticancer approach. Asian Pac J Trop Biomed 7(12): 1129-1150. DOI: 10.1016/j.apjtb.2017.10.016.

Irshad S, Mannan A, Mirza B (2011). Antimalarial activity of three Pakistani medicinal plants. Pak J Pharm Sci 24: 589-591.

Jameel S, Ahmad S, Akram M, Zainab R, Sharif A (2018). Antifungal activity in the $\mathrm{MeOH}$, aqueous and hexane extracts of Capparis deciduas. Eur J Inflamm 16: 2058739218781701. DOI: $10.1177 / 2058739218781701$.

Kant K, Walia M, Agnihotri VK, Pathania V, Singh B (2013). Evaluation of antioxidant activity of Picrorhiza kurroa (leaves) extracts. Indian J Pharm Sci 75: 324-329. DOI: 10.4103/0250474X.117438.

Koparde AA, Doijad RC, Magdum CS (2019). Natural products in drug discovery. Pharmacogn Med Plants. DOI: 10.5772/ intechopen.82860.

Kooti W, Servatyari K, Behzadifar M, Asadi-Samani M, Sadeghi F, Nouri B, Marzouni HZ (2017). Effective medicinal plant in cancer treatment, Part 2: Review Study. J Evid Based Complementary Altern Med 22: 982-995. DOI: 10.1177/2156587217696927.

Krishnamoorthy K, Subramaniam P (2014). Phytochemical profiling of leaf, stem, and tuber parts of Solena amplexicaulis (Lam.) gandhi using GC-MS. Int Sch Res Notices 567409. DOI: $10.1155 / 2014 / 567409$.

Kumar PV, Sivaraj A, Madhumitha G, Saral AM, Kumar BS (2010). In vitro Antibacterial Activities of Picrorhiza kurroa rhizome extract using Agar well diffusion method. Int J Curr Pharm Res 2: 30-33.

Mahlo SM, Chauke HR, McGaw L, Eloff J (2016). Antioxidant and antifungal activity of selected medicinal plant extracts against phytopathogenic fungi. Afr J Tradit Complement Altern Med 13: 216-222. DOI: 10.21010/ajtcam.v13i4.28.

Mahmood T, Anwar F, Afzal N, Kausar R, Ilyas S, Shoaib M (2017). Influence of ripening stages and drying methods on polyphenolic content and antioxidant activities of mulberry fruits. J Food Meas Charact 11(4): 2171-2179. DOI: 10.1007/s11694-017-9602-6.

Maru Y, Hippo Y (2019). Current status of patient-derived ovarian cancer models. Cells 8: 505. DOI: 10.3390/cells8050505.

Masood M, Arshad M, Qureshi R, Sabir S, Amjad MS, Qureshi H, Tahir Z (2015). Picrorhiza kurroa: An ethnopharmacologically important plant species of Himalayan region. Pure App Biology 4(3): 407-417. DOI: 10.19045/bspab.2015.43017.

Mbemi AT (2018). Abstract 4394: Novel edible medicinal plant induced cytotoxic and apoptotic effects on ovarian cancer cells. Cancer Res 78: 4394. DOI: 10.1158/1538-7445.AM2018-4394.

Mericli F, Becer E, Kabadayı H, Hanoglu A, Hanoglu DY, Ozkum D, et al. (2017). Fatty acid composition and anticancer activity in colon carcinoma cell lines of Prunus dulcis seed oil. Pharm Biol 55: 1239-1248. DOI: 10.1080/13880209.2017.1296003.
Milic I, Hoffmann R, Fedorova M (2013). Simultaneous detection of low and high molecular weight carbonylated compounds derived from lipid peroxidation by electrospray ionization-tandem mass spectrometry. Anal Chem 85: 156-162. DOI: 10.1021/ac302356z.

Narayan J, Varshney V (2013). Chemical constituents of Picrorhiza genus: a review. Am J Essent Oil Nat Prod 1: 22-37.

Ogbole OO, Segun PA, Adeniji AJ (2017). In vitro cytotoxic activity of medicinal plants from Nigeria ethnomedicine on Rhabdomyosarcoma cancer cell line and HPLC analysis of active extracts. BMC Complement Altern Med 17: 494. DOI: 10.1186/ s12906-017-2005-8.

Qadir R, Anwar F, Mehmood T, Shahid M, Zahoor S (2018). Variations in chemical composition, antimicrobial and hemolytic activities of peel essential oils from three local Citrus cultivars. Pure Appl Biol 7: 282-291. DOI: 10.19045/bspab.2018.70034.

Raks V, Al-Suod H, Buszewski B (2018). Isolation, separation, and preconcentration of biologically active compounds from plant matrices by extraction techniques. Chromatographia 81: 189-202. DOI: 10.1007/s10337-017-3405-0.

Roslen NA, Alewi NAM, Ahamada H, Rasad MSBA (2014). Cytotoxicity screening of Melastoma malabathricum extracts on human breast cancer cell lines in vitro. Asian Pac J Trop Biomed 4: 545-548. DOI: 10.12980/APJTB.4.2014C658.

Sasidharan I, Menon AN (2010). Comparative chemical composition and antimicrobial activity fresh \& dry ginger oils (Zingiber officinale Roscoe). Int J Curr Pharm Res 2(4): 40-43.

Sen S, Chakraborty R (2016). Revival, modernization and integration of Indian traditional herbal medicine in clinical practice: Importance, challenges and future. J Tradit Complement Med 7: 234-244. DOI: 10.1016/j.jtcme.2016.05.006.

Seo J-H, Kim J-E, Shim J-H, Yoon G, Bang M-A, Bae C-S, et al. (2016). HPLC analysis, optimization of extraction conditions and biological evaluation of Corylopsis coreana uyeki flos. Molecule. 21: 94. DOI: $10.3390 /$ molecules21010094.

Siddiqi A, Alam SS, Begum S, Nazneen Z, Aaqil B, Alam MA (2015). Evaluation of therapeutic potential of Picrorhiza kurroa glycosidal extract against nimesulide nephrotoxicity: a pilot study. J Ayub Med Coll Abbottabad 27: 312-313.

Singh R, Chaturvedi P (2019). Phytochemical Characterization of Rhizome, Fruit, Leaf and Callus of Rheum emodi Wall. using GC-MS. Pharmacogn J 11: 617-623. DOI: 10.5530/pj.2019.11.99.

Soares-Bezerra RJ, Da Silva Ferreira NC, de Almeida Alves TM, Zani CL, Rosa LH, Faria RX, et al. (2019). A new insight into purinergic pharmacology: Three fungal species as natural P2X7R antagonists. Phytother Res PTR 33: 2319-2328. DOI: 10.1002/ ptr.6412.

Suurbaar J, Mosobil R, Donkor A-M (2017). Antibacterial and antifungal activities and phytochemical profile of leaf extract from different extractants of Ricinus communis against selected pathogens. BMC Res Notes 10: 660.

Thoppil RJ, Bishayee A (2011). Terpenoids as potential chemopreventive and therapeutic agents in liver cancer. World J Hepatol 3: 228-249. DOI: 10.4254/wjh.v3.i9.228.

Truong D-H, Nguyen DH, Ta NTA, Bui AV, Do TH, Nguyen HCH (2019). Evaluation of the use of different solvents for phytochemical constituents, antioxidants, and in vitro antiinflammatory activities of Severinia buxifolia. J Food Qualit DOI: $10.1155 / 2019 / 8178294$.

Usman MRM, Surekha Y, Chhaya G, Devendra S (2012). Preliminary screening and antimicrobial activity of Picrorhiza kurroa royle ethanolic extracts. Int J Pharm Sci Rev Res 14: 73-76.

van Herten LM, van de Water HPA (1999). New global Health for All targets. BMJ 319: 700-703. DOI: 10.1136/bmj.319.7211.700.

Vijayaram S, Kannan S, Saravanan KM, Vasantharaj S, Sathiyavimal S, Senthilkumar P (2016). Preliminary phytochemical screening, Antibacterial potential and GC-MS analysis of two medicinal plant extracts. Pak J Phar Sci 29: 819-822. 


\section{Supplementary data}

Suppl. Table 1. Gradient program for HPLC based separation of

long listed phytochemicals from Picrorhiza kurroa root extract

\begin{tabular}{lc}
\hline Time (min) & Gradient pump B\% \\
\hline $0-10$ & 10 \\
$10-28$ & 40 \\
$28-39$ & 60 \\
$39-50$ & 90 \\
$50-55$ & 90 \\
$55-65$ & 10 \\
$65-75$ & 10 \\
\hline
\end{tabular}

20190208-5 NR+Sm (SG, 4×3)

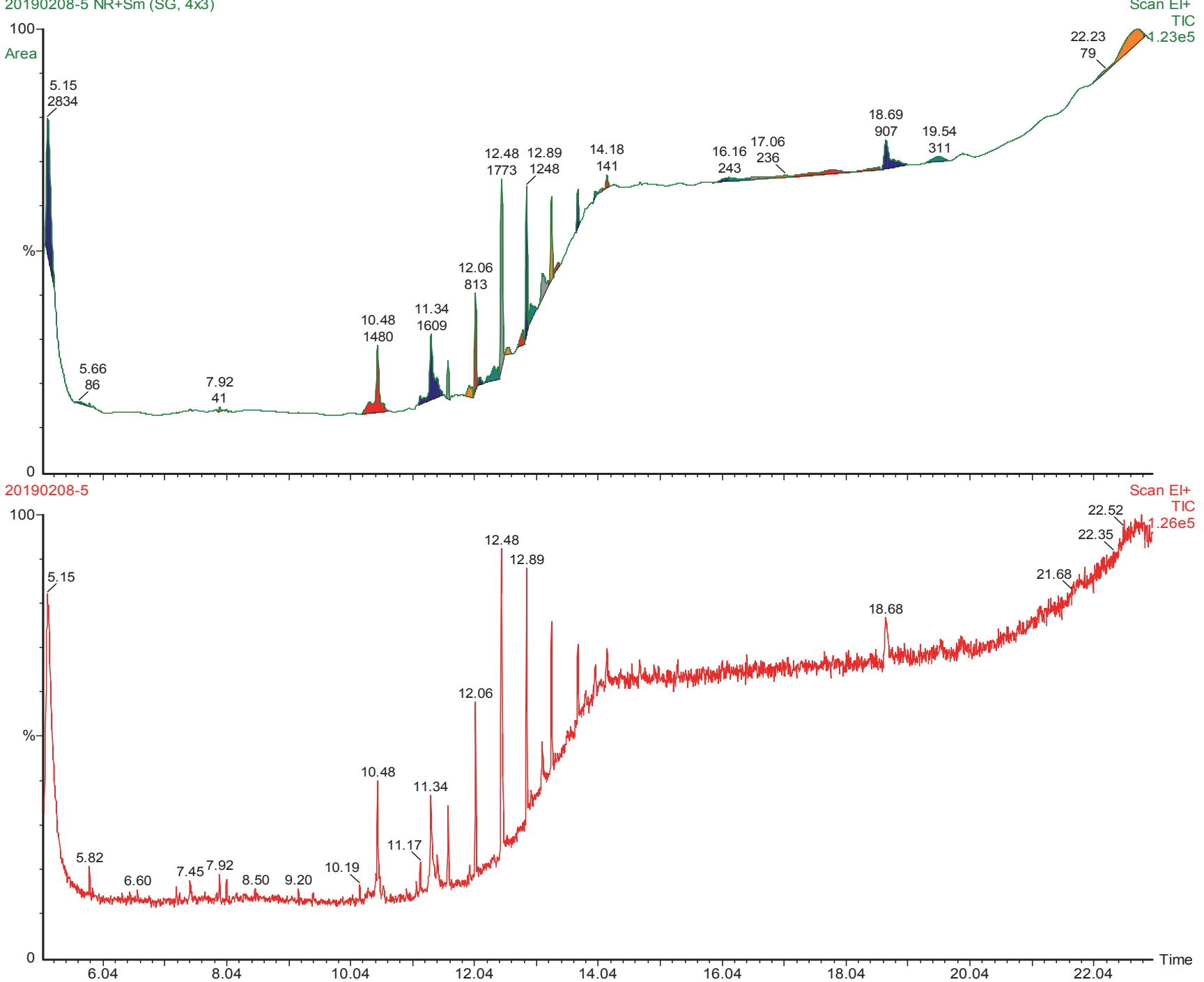

Suppl, Fig. 1. Chromatogram of GC and spectrum of MS of $n$-hexane extract 


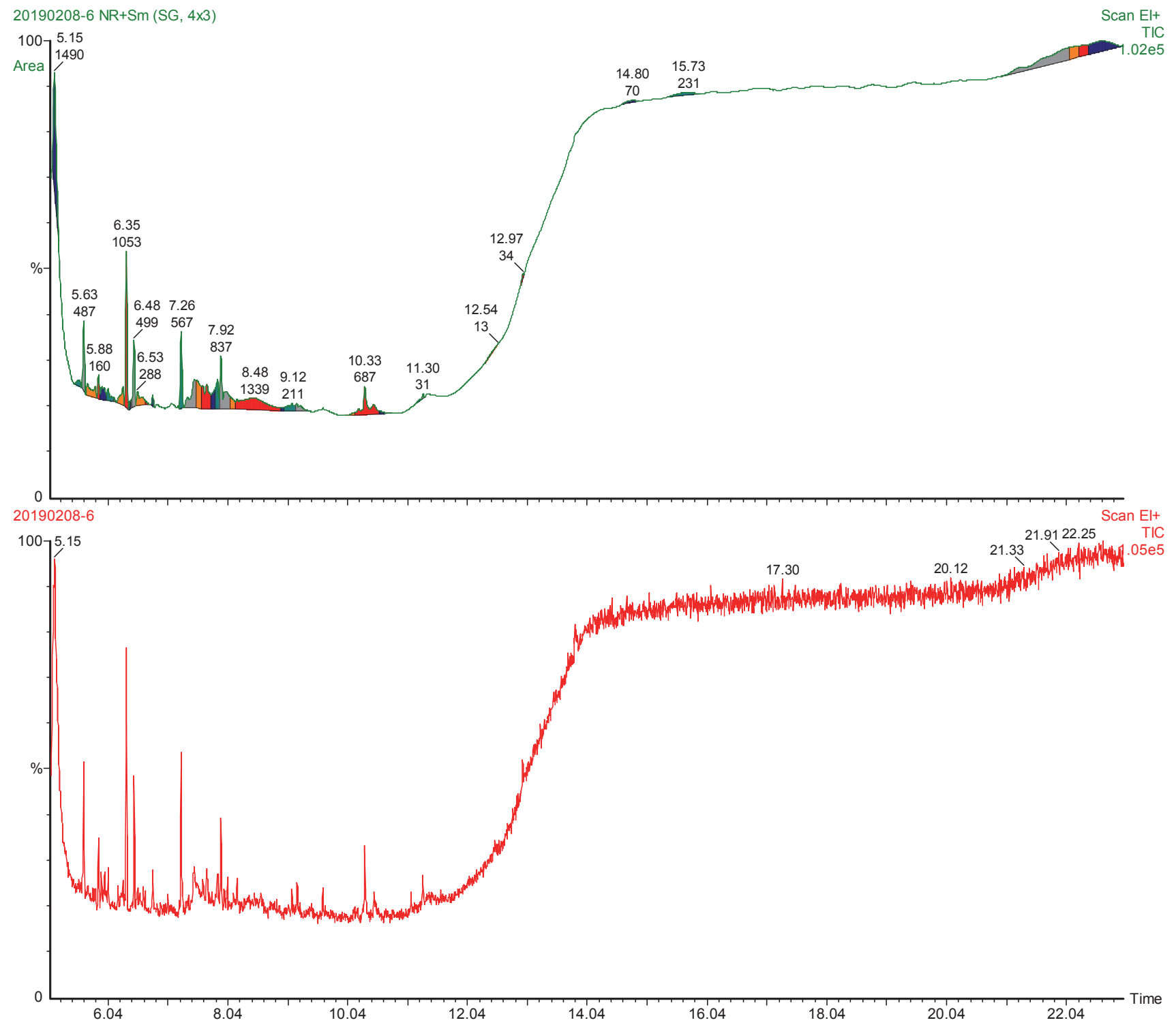

Suppl. Fig. 2. Chromatogram of GC and spectrum of MS of MeOH extract 
$<$ Chromatogram>

mAU

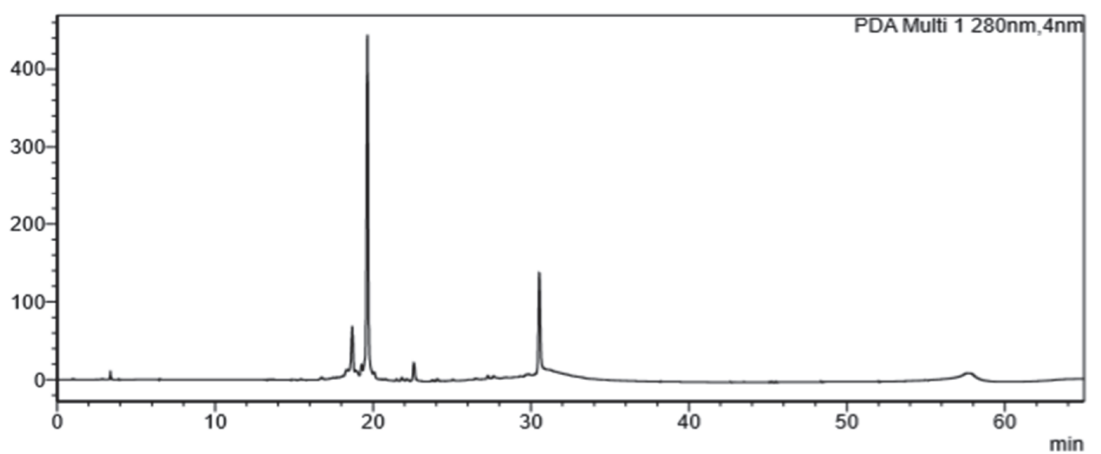

\section{Generic Display Report}

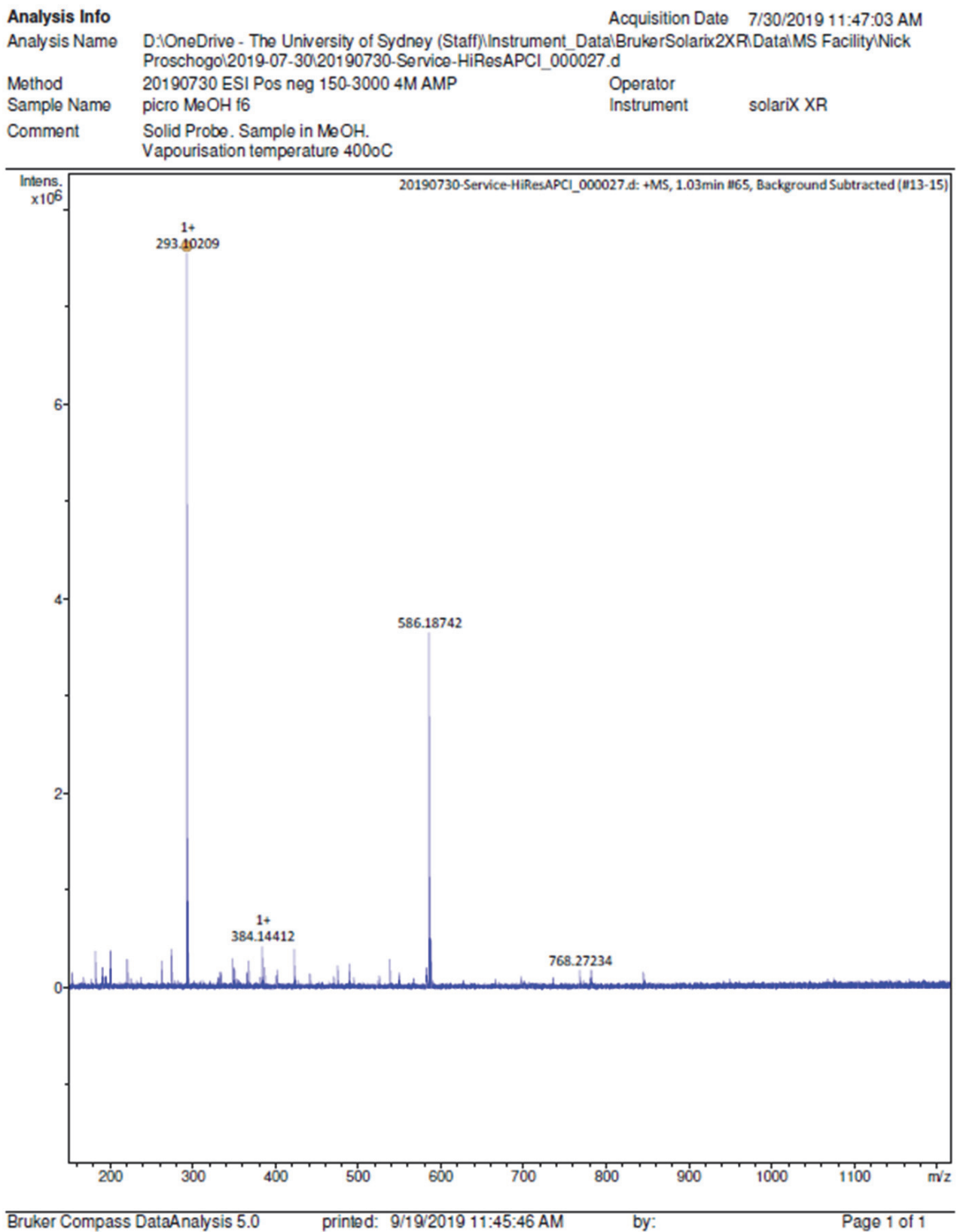

Suppl. Fig. 3. Chromatogram of $\mathrm{MeOH}$ extract with major peak of compound 1 (dihydromikanolide 1 and HR-APCI-MS of partially purified $\mathrm{MeOH}$ extract 

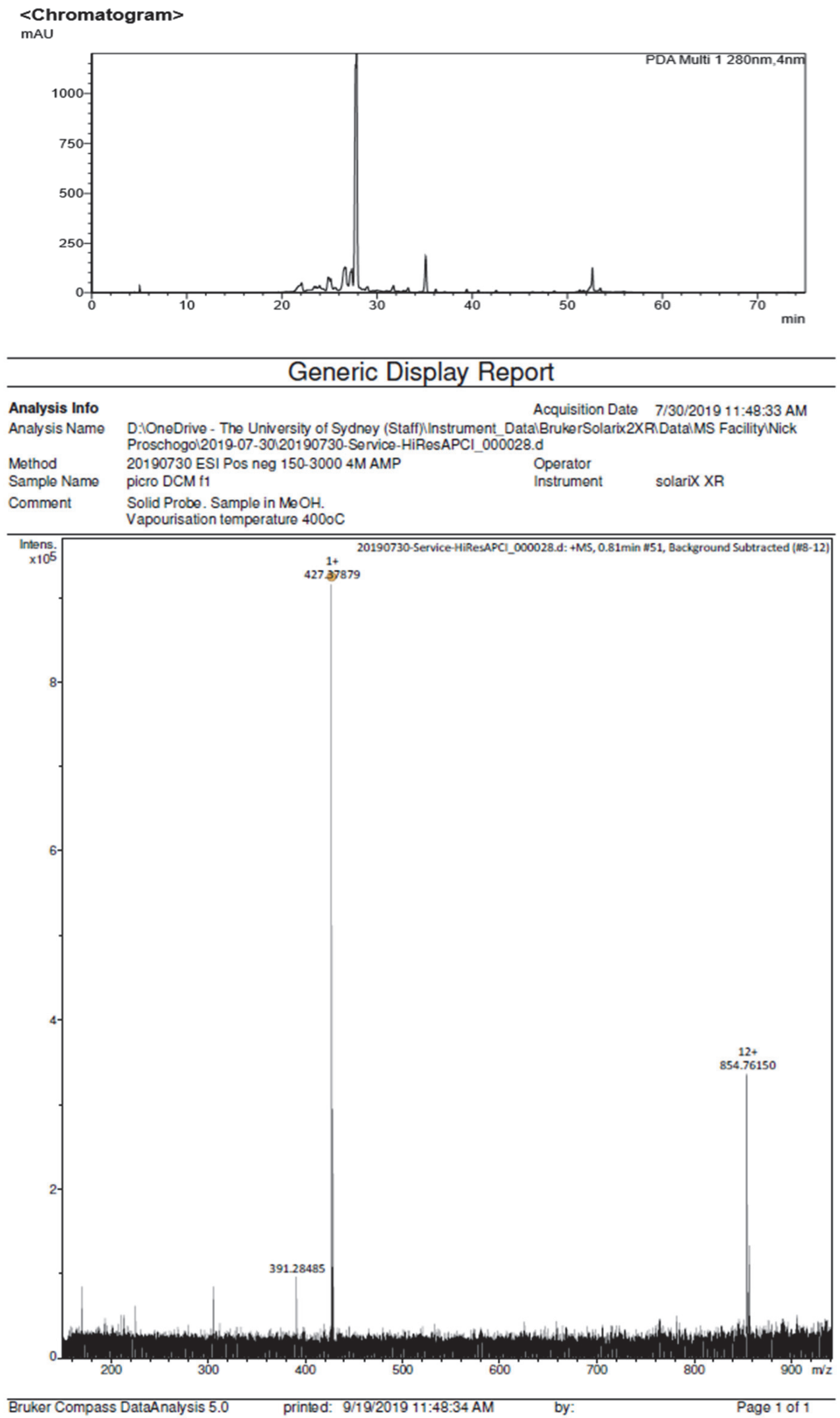

Suppl. Fig. 4. Chromatogram of a fraction of $\mathrm{CH}_{2} \mathrm{Cl}_{2} / \mathrm{H}_{2} \mathrm{O}$ extract with major peak of compound 2 and HR-APCI-MS spectrum of partially purified $\mathrm{CH}_{2} \mathrm{Cl}_{2} / \mathrm{H}_{2} \mathrm{O}$ extract 